\title{
How do Museums Affect Sacredness? Three
} Suggested Models

Comment les musées affectent-ils le sacré? Trois modèles suggérés

\section{Helena Wangefelt Ström}

\section{(2) OpenEdition}

12 Journals

Electronic version

URL: http://journals.openedition.org/iss/1917

DOI: 10.4000/iss.1917

ISSN: 2306-4161

Publisher

ICOM - International Council of Museums

\section{Printed version}

Date of publication: 12 October 2019

Number of pages: 191-205

ISBN: 978-92-9012-467-2

ISSN: 2309-1290

Electronic reference

Helena Wangefelt Ström, "How do Museums Affect Sacredness? Three Suggested Models », ICOFOM Study Series [Online], 47(1-2) | 2019, Online since 12 October 2019, connection on 10 December 2020. URL : http://journals.openedition.org/iss/1917 ; DOI : https://doi.org/10.4000/iss.1917 


\section{How do \\ Museums Affect Sacredness? \\ Three

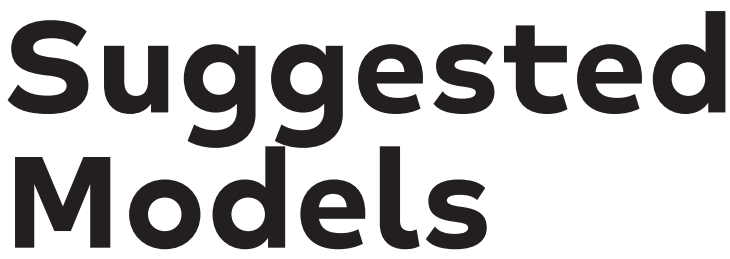

\section{Helena Wangefelt Ström Umeå university and Uppsala university, Umeå and Uppsala, Sweden}

ABSTRACT

This paper discusses what happens when religion in the shape of objects imbued with religious meaning is transformed into cultural heritage, suggesting three models to discuss its consequences for museums. The first model builds on the museum as a killing of previous identities, and the objects as provided with new identities as museum objects. A second model is the hybrid identity, where a museum object can possess several identities simultaneously, depending on the eyes of the beholder: sacredness, art object, or evidence of history. The third model is defined by the uses of objects. Distinguishing between cultual use and cultural use is crucial here. I argue that these different approaches to sacred objects in museum pose different museological challenges and possibilities, and also ascribes different agencies to museum staff as well as to the visitors. 
Key words: Heritage, Religious heritage, Heritagization, Materiality, Zombie identity

\section{RÉSUMÉ}

\section{Comment les musées affectent-ils le sacré ? Trois modèles suggérés}

Cet article traite de ce qui se passe lorsque la religion se transforme en patrimoine culturel sous la forme d'objets imprégnés d'une signification religieuse. Il propose trois modèles pour discuter de ses conséquences pour les musées. Le premier modèle s'appuie sur le musée pour détruire les identités précédentes, les objets étant dotés de nouvelles identités en tant qu'objets de musée. Le second modèle est hybride, un objet de musée pouvant posséder plusieurs identités simultanément, selon les yeux du spectateur : caractère sacré, objet d'art ou preuve de l'histoire. Le troisième modèle est défini par les différentes utilisations des objets. La distinction entre usage cultuel et usage culturel est cruciale ici. Je soutiens que ces différentes approches des objets sacrés dans les musées posent des défis et des possibilités muséologiques différents, et attribuent également différentes agences au personnel du musée ainsi qu'aux visiteurs.

Mots clés : Patrimoine, Patrimoine religieux, Patrimonialisation, Matérialité, Identité zombie

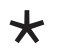

What happens when religion in the shape of objects imbued with religious meaning is transformed into cultural heritage? The relation between religion and museums has been the topic for a number of recent publications from different parts of the world, focusing different religious traditions (for example Paine, 20I3; Merleau-Ponty, 20I7; Buggeln et al., 20I7; Sullivan, 20I5; Berg \& Grinell, 2018; Capurro, 2013). Among the factors involved to understand this topic, identity and perception appear to be central. Drawing from my ongoing PhD project at Umeå university, in which I try to trace back in time the musealising way of accounting for religious objects, I employ a case study taking place in early modern Rome and Venice.

In this paper I introduce some reflections on this theme of identity and transformations tied to sacredness in museums, and clarify how I understand some of the key concepts within this field. I suggest three models to discuss the shifting identities, processes of heritagisation of religion, and the factors involved, giving examples from different times and contexts to illustrate the model. I 
conclude by briefly suggesting some points in relation to museum practice for further reflection.

\section{Religion as heritage, religion in museums - and religious museums}

In order to examine how museums as institutions and a heritage identity affect religion, let us start by looking at the concepts. What is heritage, and what is a museum? Heritage can be in a museum, and a museum can be part of a heritage, but they do not have to be; 'heritage' might be the zone where the museum world and the visitor world intersect (Dicks, 2003). Museums are undergoing major changes: in terms of uses of various new media including the internet, and in new expectations to be active parts in contemporary debates and to address issues at stake in our time. All this, while simultaneously maintaining their more traditional role as knowledge producers and materialisers of culture, that is to explain and illustrate culture through objects and other materiality (Macdonald \& Fyfe, 1996). The museum in this sense is a multi-layered and complex concept far from the traditional temple for the cult of history (Davis et al., 20Io). The traditional object-centred way of displaying objects and processes in museums, where the object is supposed more or less to speak for itself, can even be likened to a monstrance, the artistically elaborated framing of a consecrated hostia being displayed to the faithful in Catholic rite (Mairesse, 20I4).

Barbara Kirshenblatt-Gimblett (I998) states that heritage is created through detachment, the creation of fragments, a process of exhibition, and with an agency of display. An aspect of heritagisation - that is, the creation of heritage - is its "rendering defunct" function, and how this necessarily presupposes death and oblivion.

All kinds of efforts at preservation, all reworking of history and all kinds of revival presuppose and are based on evanescence and death. To remember is a prelude to forgetting; in the case of the cultural heritage industry, it is not memory but oblivion which lies at its core, because it is out of forgotten and dead things that cultural heritage is fashioned [...] Cultural heritage and museums evoke the idea of the living because they require and base their work on the left over, the discarded and the defunct (Ronström, 2008).

'Heritagisation' thus is an act which transforms its objects by turning them into exhibits, and as we see, death is perceived as a fundamental part of this process. It is a political process, which establishes power over the past, the present and the future (Ronström, 2008). 'Musealisation' refers to the process when something is transferred from the sphere where it was created and func- 
tioned to the museum. Macdonald (1996) emphasises that 'alive' is a keyword in contemporary museum promotional literature; this in contrast to heritagisation as an act connected to death (Kirshenblatt-Gimblett, 1998). According to this scholarship, the tension between the extreme positions of life and death are at the core of the museum identity. This tension, as we shall see, is most relevant for the field of religion in museums.

So, what happens when religion is (re-)contextualised in a museum? Religion in museums can take on many shapes and be staged by a number of actors with most different agencies and aims. Rita Capurro (2013) suggests five different categories:

- Religious museum. Museum with particular reference to religion, including ecclesiastical museums, or those which through collections, mission, choice of narrative, refer to religion.

- Museum of religions. Museum aiming at presenting various religions of the world.

- Museum for sacred art. Occupied mostly with collections of sacred art, or with objects referring to a cult.

- Ecclesiastical museum. Museum directed and owned by an ecclesiastical entity, with collections that can span from sacred art to scientific collections.

- Confessional museum. Institution expressing a group or a religious confession. Auto-representative narratives mirroring the ideals and ideologies of the current confessions.

This division shows us that religion in museums can be many things, and be designated to tell many and most different stories spanning from anthropology and social history to history of religion and collections of objects for religious devotion. Still, no matter the intentions of the museum, some museum visitors tend to move between and across the designated categories by for example praying or sacrificing flowers before a religious image in an art museum (Paine, 2013): a kind of visitors' rebellion against normative categorising? This visitor behaviour, outside of the traditional interaction in a museum context, presents new challenges to museum curators and conservators. The practice in some religious spaces to let believers who wish to pray enter for free while "tourists" are charged an entrance fee also ties into this: what can we actually know about the thoughts within a human mind? And should we ask about it?

\section{Religious, spiritual, holy, or sacred?}

Continuing to clarify the values and uses of terms connected to our topic, we may notice that the terminology is all but homogenous in the interface between heritage and religion in different fields. The formulations used in UNESCO's Initiative on Heritage of Religious Interest (http://whc.unesco.org/ en/religious-sacred-heritage/) display a somewhat ambiguous use of the terms 'religious', 'spiritual', and 'sacred': 
The term "Religious property", as used in the ICOMOS study Filling the Gaps - an Action Plan for the Future, defines «any form of property with religious or spiritual associations: churches, monasteries, shrines, sanctuaries, mosques, synagogues, temples, sacred landscapes, sacred groves, and other landscape features, etc.».

The term «Sacred site» embraces areas of special spiritual significance to peoples and communities; and the term of «Sacred natural site» corresponds to the areas of land or water having special spiritual significance to peoples and communities, as proposed by the UNESCO/IUCN Guidelines for the Conservation and Management of Sacred Natural Sites (2008).

According to ICCROM, living religious heritage has characteristics that distinguish it from other forms of heritage. [...] Collectively, the religious and sacred properties capture a range of cultural and natural diversity, and each can singularly demonstrate the spirit of a particular place.

\section{9}

In this context, the term "religious" appears to be connected primarily to constructed sites, if landscapes are also included, while "sacred" is related to nature and natural sites. Sacred sites are also characterized by being protected since ancient times. "Religious" and "spiritual" are both used to indicate a cultural and traditional connection to the divine, but in many cases - as in the previous quote - the latter is used to define something outside of the institutionalized and organized beliefs. As Crispin Paine describes the preconditions for his first book on religion in museums, Godly Things (in Paine, [2000] 2013):

Formal religion [my emphasis] was fast declining in much of Western Europe (though spirituality [my emphasis] wasn't), but in much of the rest of the world religion was becoming ever more powerful and so more political.

\section{9}

The term "sacred" indicates, according to historian Alphonse Dupront (I993), not just a definition but also a method to categorise items and phenomena in the religious sphere. Sacredness is the almost physical presence of God in human bodies, actions, and divine - human interactions. Some places, objects, relics and saints can also be considered holy: the term "holy" indicates that the divine qualities are inherent and given by divine power - contrary to the sacred, which is an identity created within a religious context, but by means of human decisions. 
If we go for these understandings of concepts, we are facing a range of religious objects and spaces where some, in the eyes of the believer, are made permanently holy by a divine power and some are given a reversible sacred charge by means of human rituals. Some of the objects and spaces are found in institutions (religious or non-religious museums and exhibitions), while some are found in nature. No matter what, these religious objects and spaces (or fragments thereof) may one day end up in a museum collection, and at this point the museum may want to take into consideration these - to some, but not all beholders - intangible but most potent qualities.

\section{Sacred and holy objects: uses and transformations}

Having settled how to understand the terminology and basic concepts in our field, let us move on to the uses of religion and sacredness. Religious objects can be used in many ways: museum use is just one out of many options. The original uses of the sacred and - more widely - the religious past, obviously is the religious use of the sacred in a religious context. Sacred uses of sacredness extend outside of holy places: the most frequent use, in many if not all religions and denominations, is the use in liturgy and devotion. Sacred or holy qualities are ascribed to objects of shifting kinds, by long tradition in some religions, and against the theological fundaments in other. An example of the latter are the material Luther relics - belongings, pieces of letter signatures (so-called grapho-relics, which could be cut up in small pieces and be distributed among the followers), and so on - which developed over time among the faithful Lutherans, interestingly enough in the context of the Lutheran denouncing of sacred meaning in objects (Wharton, 20I4; Walsham, 20IO; Rublack, 20Iо).

In order to understand the preconditions of the question at the core of the topic of this paper a little better, let us remain for a while in Western European history, and the century following the Reformation and the Counter-reformation. This period was characterised by a need to define and categorise the sacred in order to defend and protect it: it was a matter of great importance also outside of the boundaries of theoretical and theological principles. Forming categories for sacred images and sacred art became an urgent task in the aftermaths of the iconoclasm following the Reformation in some European countries: Cardinal Paleotti's Discorso intorno alle immagini sacre e profane ( 1582 ) is one example. Protection from external dangers and threats - which, according to a common definition in contemporary heritage scholarship is a major motivator behind heritagisation (Harrison, 20I2) - was the driving force, and the result was limitation, musealisation, heritagisation and disenchantment. Equally crucial was the eagerness to categorise in general and to distinguish categories, which is one of the foremost characteristics of Modernity. Religion and sacredness became categories, and categories possible to arrange and rearrange in new settings - art cabinets, collections and treasuries, art markets, scientific collections and early museums. With new settings followed, during 
the early modern period, new stories, new beholders, and new ways of seeing and understanding the sacred - or to disregard it completely and choose to see nothing but art and history.

To further look into the matter of shifting identities in religious objects, let us go outside of Christianity. In traditional Judaism, ritual objects are divided into two categories: those that have a quality of holiness in themselves, and those essential to perform particular rituals or commandments but have in themselves no quality of sacredness or holiness. Holy objects in Judaism, called tashmishey kedusha (accessories of holiness), include primarily the Torah scroll and items connected to it and to written holy words. When these objects are no longer fit for ritual use they are buried, sometimes in a special area of a Jewish cemetery or close to a particularly spiritual and learned man, or they are placed in a geniza, a special room in the synagogue. Items within the second category, the ones essential for rituals but not perceived as holy in themselves, can be treated by a conservator and handled as ordinary heritage objects without problems (Greene, 1992).

What we see here is yet another example of a division between holy and sacred objects, and of how these are being used not only in the intended liturgical context, but also in their state of retirement and disuse. This division is highly relevant from a museological point of view, and similar examples can be observed in many religions (Mibach, 1992).

Having touched upon with what words and concepts religious objects and their identities are described and used, including the idea of a division between "alive" and "dead" objects, we shall now move onto the visitor's point of view, namely the seeing and perceiving of religious objects and spaces in a museum or heritage context.

\section{What do museums do to religious objects? Three suggested models}

To visualise three ways in which the effects of museums on religious objects can be regarded in light of current theoretical frameworks and museum practices, I suggest three models demonstrating three slightly different views and approaches. 


\section{Model I: Euthanized sacredness}
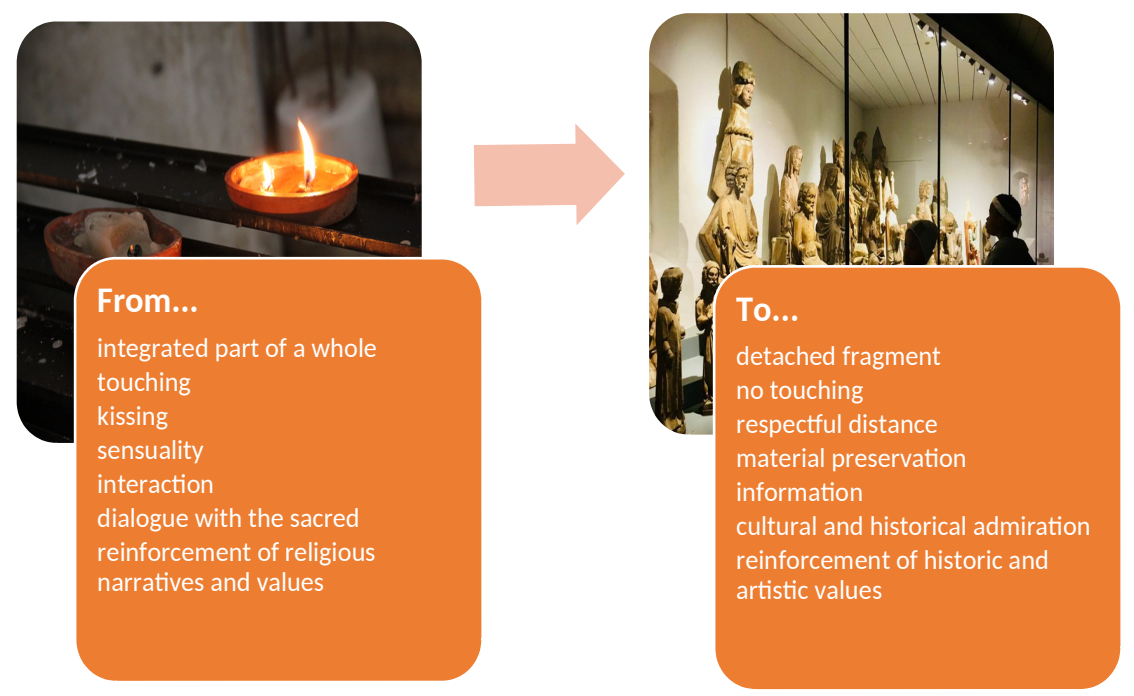

Fig. I. Euthanised sacredness: from life to death, to a new museum life.

(Figure and photos by the author)

A frequently used scholarly model to explain heritagisation depicts the museum as a place for killing of previous identities, and the objects transferred there as provided with entirely new identities, and lives, as museum objects (Kirshenblatt-Gimblett, I998; O'Neill, 2015). This view affects sacred objects, how they are handled and narrated in the museum, and possibly also how they are viewed by the visitors. The use - or not - of information signs before sacred objects in museums is an aspect on this matter: this is an ongoing discussion, and some churches and other sacred spaces refrain from information signs in order to avoid being understood as a museum. The musealisation effects on sacred matter here implies a one-way transformation, for example from touching to no touching, from interaction to information, from sensuality to respectful distance, and from sacred to heritage, material and artistic identity. Contemporary examples of this view are numerous: in museums, and in sacred spaces addressing tourists. Objects and spaces are presented in terms of materiality, year of production, names of artists, monetary value, and so on, while information on the spiritual values for believers, or the reason for making the object in the first place, is often lacking.

This model in practice gives the museum curator a freedom to re-contextualise the sacred and/or religious objects within a framework of, for example, art, history, decoration, crafts, or contemporary art. Since the objects are detached fragments, the possible sentiments of a religious beholder do not pose a problem. 


\section{Model 2: In the beholder's eye}

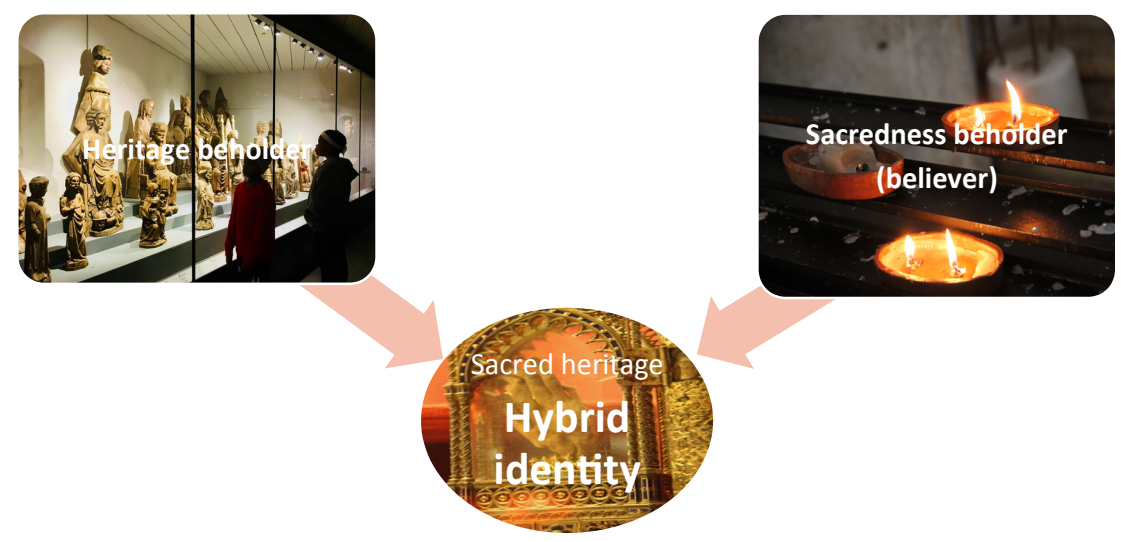

Fig. 2. In the beholder's eye. (Figure and photos by the author)

The second model is the hybrid identity, where a museum object can be said to possess two authentic identities simultaneously, depending on the views and beliefs of the beholder: authentic sacredness, or authentic art object and evidence of history. This view responds well to the focus in our time on the individual. It does not force the museum to take a stand regarding any true identity of the object - however, it does require an informed policy for managing and displaying the objects in a way that is not offensive to the believer.

The beholder's eye is not only about an individualized view: it can also cause trouble. If we for a moment return to the early modern period, we find that the rapidly growing influx of peregrination travelers and, with time, leisure travelers in cities like Rome and Venice affected also the field of religion. A recurrent theme in accounts of these foreigners and their ways of seeing things is the presence of fear and suspicion: of the foreign, of the heretic and dissenting and non-conformist, and of losing power and prestige. The tension within these matters was such that the mere presence of a dissenting foreigner could prove fatal to local religious life. This potential problem was not unique to Rome and Venice, or to the $\mathrm{I}^{\text {th }}$ century, as we can see in the following examples from $\mathrm{I} 8^{\text {th }}$ century Naples, all giving glimpses of controversies around the display of a famous blood relic - not in a museum, but with the foreign visitor's perception in focus:

Montesquieu visits Naples the 30 April I730 on his journey in Italy and witnesses the famous liquification miracle in which the dried blood of a famous local saint, St. Gennaro, becomes fluid in an annual religious service. After the miracle, Montesquieu overhears one priest whispering to another: «The miracle occurred, and there were nine heretics!»: obviously, the presence of non-Catholics posed a potential problem for the miracle to happen. (Montesquieu, 
on his part, thought the saintly blood in fact was some kind of thermometer) (Montesquieu, [1728-29] I97I).

English visitors - a common type of leisure travelers to $\mathrm{I}^{8^{\text {th }}}$ century Italy - who attended the same annual relic ceremony in Naples were regarded with great suspicion by the local parishioners. According to a priest, the heretic strangers also fall prey to fanaticism when faced with this unusual level of sacredness: the women tore their hair and beat their chests, and sometimes, the miracle was delayed or did not happen at all (Saint-Non $\mathrm{I}_{7} 8 \mathrm{I}$ ). This was seen as a most ominous event for the city, and the clergy took great measures to prevent all interferences with the saintly transformation. In I78I, Abbé de Saint-Non accounts from a St. Gennaro celebration:

This disbelief is causing worried looks upon witnesses that can be assumed of having a suspicious faith. And we saw foreigners become the victims of a devotion suddenly changed into fanaticism. An English Consul who attended this ceremony was, at one of these dangerous moments where the favours of the Saint were delayed for too long, asked to retire; and the Miracle occurred shortly after, leaving the people in no doubt as to guess the reason for the delay (Saint-Non, 1781).

This observation on the part of the priest, that the English consul could cause disturbances in the sacred ritual just by standing too close to the altar gives us an idea of the effects not only of objects on visitors, but also the other way around.

Relics had a status of a prime point of interest and connected to the identity of a place for travelers ever since the pilgrimages to the catacombs started, and after the Reformation this habitual way of presenting a place and its treasures caused cultural clashes. The display of and devotion connected to relics was, understandably, one of the most delicate and obvious areas of conflict between the Catholic and the Protestant way of understanding and valuing religious materiality. Another example, now from $\mathrm{I} 7^{\text {th }}$ century France, is Lord Fountainhall, a Scottish Presbyterian who saw relics for the first time at the age of 2I when visiting the Benedictine monastery of Marmoutier during a journey in $1665-67$. He was shown, in a museum like setting, the heart of St Benedict enclosed in a crystal jar beset with diamonds: an utterly strange object to the non-Catholic visitors. There was a company of six tourists, all "of the Religion, whence we had no great respect for the relics, but their ware some others there that were papists; who forsooth bit to sit doune on their knees and kist. At which I could not contein my selfe from laughing" (Mączak, 1995). The Catholics in the company saw sacredness, and knelt before and kissed the relic, while the Presbyterians saw a strange and macabre object, and burst out 
in laughter: most likely a delicate challenge for the tour guide. Going back to our time, it is not a far-fetched thought to imagine similar challenges in museums today, with culturally heterogeneous groups of visitors and displays not always taking into account that they might be walking on someone else's holy ground.

\section{Model 3: A multi-tool for shifting needs, or the Zombie model}

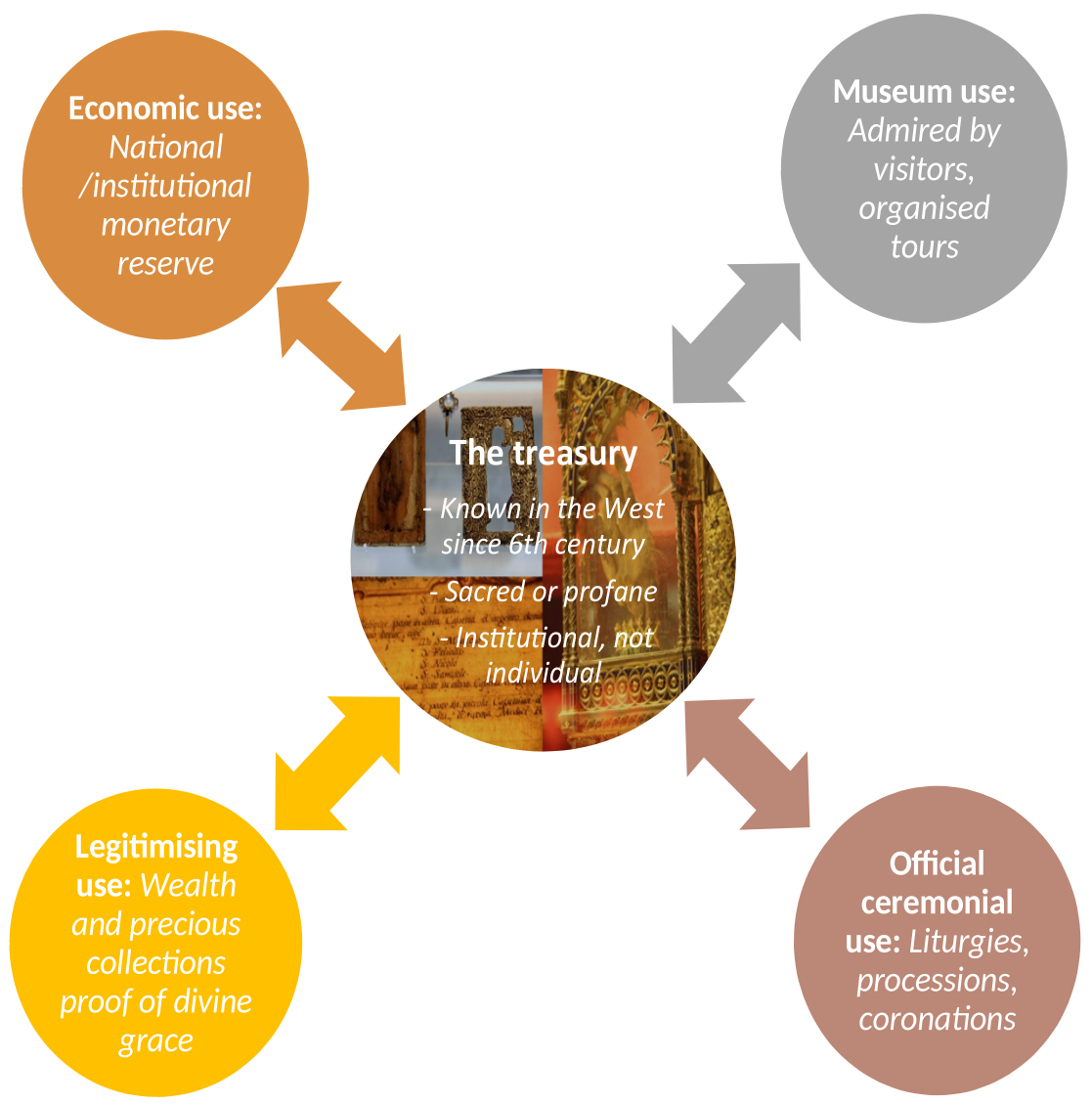

Fig. 3. The Zombie model: in and out of identities, along with shifting uses. (Figure and photo by the author)

The third model suggested is based on the two previous ones, but defined not by decisions on identity or by individual views, but by decisions on shifting uses. The objects are allowed to be alive and dead (in the sense used in Model I): a kind of Museum "Zombies". As an example here, I use the image of a treasury, that is an early prototype for a museum with guided tours, visitors from different backgrounds, and famous highlights.

Let us take a closer look at the treasury, its place and function in the tradition of collecting and, eventually, in the forming of museums. What is a collection, 
and how does it affect sacredness? According to Krzysztof Pomian (2004), a collection can be defined as follows:

Ensemble of natural and artificial objects, kept temporarily or definitively outside of the circulation of economic activities, subject to a special protection and exposed to the gaze in a closed, specially equipped place, the collection is a universal matter, co-existing in time with Homo Sapiens and confirmed, also in rudimentary form, in every human society.

The collections as entities and products of their time have changed character and motives for existing through history, and have been situated in different parts of society and physical space. The first type of collections that can be clearly identified in the West are the treasuries, dating back to the $6^{\text {th }}$ century if also with even older roots. The treasury was an entity that could have either an ecclesiastical and sacred identity, or a princely and profane one. It was a heterogeneous composition of relics in reliquaries, gold and silver objects, precious stones and textiles, and its function was to visualize the power and the wealth - signs of divine protection - of the institution in whose possession it was, rather than the individual tastes of the individual who was temporarily in charge of this institution (Pomian 2004). Consequently, the treasury could be used as a financial reserve to be sold in parts or melted down and transformed to coins in case of economic difficulties. Moreover, it functioned as a depository for valuable objects used occasionally, such as liturgical objects and relics, that were taken out and displayed for devotion, and then returned to the treasury: a flow back and forth between cultural and finacial identy on one hand, and cultual identity on the other. Pomian has coined the term semiophor, "sign-bearer", for objects that change significance and charging, and represent different meanings in different contexts, and I find it highly applicable to the changing identities and charges in religious objects.

Collecting and collectors have evolved over time, which is evident not least during the $\mathrm{I}^{\text {th }}$ century. During the period, there was a contest in the purpose of collections between the admiration of beauty and the useful study of nature and art, and the shift from treasury to private collection also meant a shift in roles, from proprietor to collector. In the course of the $17^{\text {th }}$ century, the wunderkammer collections that had similiarities with the medieval treasuries but still was an entirely different construction of macrocosm projected in a microcosm, gradually evolved into collections less focused on fascination and traces from the past, and more on satisfying the curiosity and needs of the new science. In this development of displays and exhibitions, the religious art and the sacred objects from various religions entered and blended into the circulation and re-calculation of objects, and new understandings were possible to apply to them. 
Interesting for our question of identity is that the various uses are dependent on someone making decisions on what use to apply to the object at a certain occasion. This means that the identity within the object is temporary, and the result of a decision. These shifting identities bring challenges and call for revised practices within heritage management, regarding rules for conservation and handling of the objects for example when using religious items from a museum collection in rituals, or when allowing visitors to interact with the objects by placing flowers, or kissing or caressing, at certain occasions. A distinction between cultual use and cultural use is useful for this model.

\section{Conclusions}

The different approaches to sacred objects in museums outlined in this paper pose different museological challenges and possibilities, and ascribe different agencies to museum staff as well as to the visitors. The question of the identity of an object - sacred, or not? - is crucial in order to handle, display and narrate religious objects in museums. I outline three models to point at how and by whom the identities are created: by the ones performing the musealisation (the museum staff or the decision makers placing things in museums), by the beholders, or by the ones deciding what uses to apply to the object at certain times and in different situations. These models challenge the museums in terms of care and preservation, displays and narratives, and restrictions for handling and physical interaction. However, in a time of increasingly multi-cultural societies, a global tourism with culturally and religiously heterogenous beholders, and a post-secular curiosity for religion and sacredness, the museums need to take into account that the religious objects might still be alive (in the sense indicated in Model I) - and to treat them accordingly.

Issuing general recommendations for museums may go beyond this paper, or even be a topic for an expanded study of its own. However, a few suggestions can be made as food for further reflections:

- Learn not only of material and historical facts about a sacred object, but also of religious practice and possible religious legislation connected to it - thereby understanding possible risks of offensive displays and narratives. To what measure such practices should shape exhibitions is a separate question, but basic religious know how is needed to make informed decisions.

- Pay attention to sacred objects and spaces where touching and kissing, or other kinds of physical interaction, is traditionally involved. Does the museum wish to prepare for, or even welcome, this religious use of the object or space from believing visitors? If so: How can this be solved from a conservation point of view?

- If multiple uses of a sacred object (as in Model 3 ) are asked for, and possible: how can the transfer back and forth between religious use and museum display be facilitated? What is needed from the different 
stake holders to ensure that sacred heritage objects can function in their religious role without being damaged?

As we have seen, religion and sacredness can be displayed, and be beholded, in numerous ways: in museums connected or not connected to religion in different ways, in heterogenous collections out of religious context, or "in action" as sacred utility objects. Returning to the initial question on identity, I am tempted to propose a dramatic end to this paper: religion in museums may actually be a question of life and death.

\section{References}

Berg, M., \& Grinell, K. (2018). Musealt islam. Molin \& Sorgenfrei förlag

Buggeln, G., Paine, C., \& Brent Plate, S. (2017). Religion in museums: global and multidisciplinary perspectives. London: Bloomsbury

Capurro, R. (2013). Musei e oggetti religiosi. Arte, sacro e cultura religiosa nel museo. Milan: Vita e Pensiero Editrice

Davis, A., Mairesse, F., \& Desvallées, A. (Eds.). (2010). What is a museum? München: Verlag Dr. Christian Müller-Straten

Dicks, B. (2003). Culture on display: the production of contemporary visitability, Issues in cultural and media studies. Buckingham: Open University Press

Dupront, A. (1993). Il Sacro. Crociate e pellegrinaggi, Linguaggi e immagini. Turin: Bollato Boringhieri

Greene, V. (1992). 'Accessories of holiness': Defining Jewish sacred objects, Journal of the American Institute for Conservation, 31(1), 31-39.

Harrison, R. (2012). Heritage: Critical Approaches. Abingdon: Routledge

Kirshenblatt-Gimblett, B. (1998). Destination Culture. Berkeley: University of California Press

Macdonald, S., \& Fyfe, G. (1996). Theorizing museums: representing identity and diversity in a changing world. Oxford: Blackwell

Mączak, A. (1995) Travel in Early Modern Europe. Cambridge: Polity Press

Mairesse, F. (2014). Le culte des musées. Bruxelles: Académie Royale de Belgique

Merleau-Ponty, C. (2017). Du lieu de culte à la salle de musée - Muséologie des édifices religieux. Paris: L'Harmattan

Mibach, L. (1992). Introduction: The conservation of sacred objects. The Journal of the American Institute for Conservation (JAIC), $3 \mathrm{I}(\mathrm{I}), \mathrm{I}-2$. 
Montesquieu, C. ([I728-29] I97I). Viaggio in Italia. Grandi opere. Bari: Editori Laterza.

O'Neill, M. (2015). Museums and mortality, Material Religion. The Journal of Objects, Art and Belief

Paine, C. ([2000] 2013). Godly things: museums, objects and religion. Leicester, UK: Leicester University Press.

Paine, C. (2013). Religious objects in museums: private lives and public duties. London: Bloomsbury

Paleotti, G. (I582). Discorso intorno alle immagini sacre e profane. Bologna

Pomian, K. (2004) Dalle sacre reliquie all'arte moderna: Venezia-Chicago dal XIII al $X X$ secolo. Il Saggiatore

Ronström, O. (2008). Kulturarvspolitik. Visby: från sliten småstad till medeltidsikon. Stockholm: Carlsson bokförlag

Rublack, U. (20I0). Grapho-Relics: Lutheranism and the Materialization of the Word. Past \& Present, 206, I44-I66. DOI: https://doi.org/Io.IO93/ pastj/gtqoi6

Saint-Non, J-C. de et al. (I78I). Voyage pittoresque ou Description des royaumes de Naples et de Sicile... Premier [- Quatrième] volume.... Vol. I

Sullivan, B. M. (Ed.). (2015). Sacred Objects in Secular Spaces: Exhibiting Asian Religions in Museums. London: Bloomsbury

UNESCO. Heritage of Religious Interest. UNESCO Initiative on Heritage of Religious Interest. Retrieved on 23/8/20I7 from http://whc.unesco.org/en/ religious-sacred-heritage/

Walsham, A. (2010). Introduction: Relics and Remains. Past \& Present, 206 (suppl_5), 9-36.

Wharton, A. (20I4). Relics, protestants, things. Material Religion, IO(4), 4I2-430. 